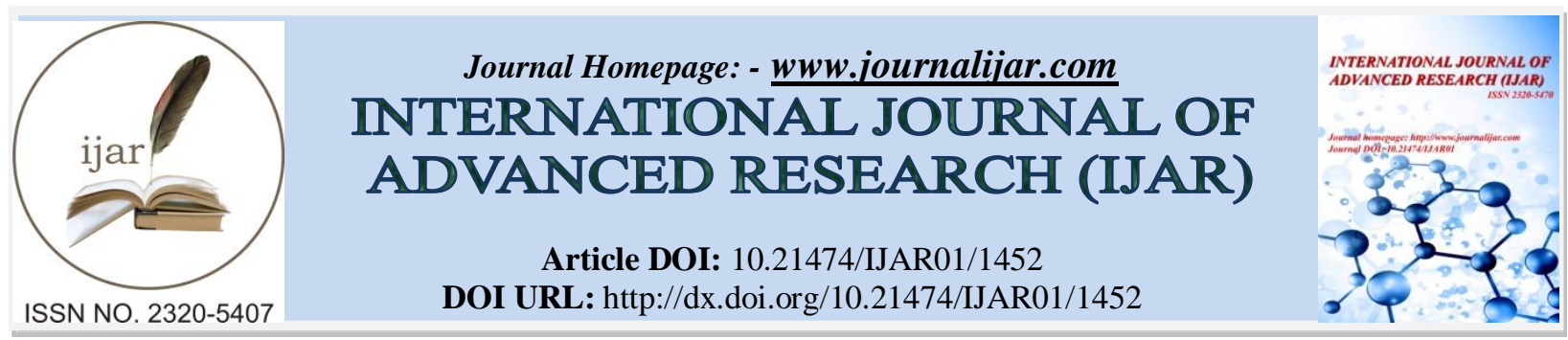

RESEARCH ARTICLE

\title{
WATER QUALITY ASSESSMENT OF LAKNAVARAM TANKOF WARANGAL, TELANGANA, INDIA.
}

\author{
*Rev. Dr. J. W. Prakash. \\ Principal, Bishop Jesudasan Junior College, Etturnagaram, Warangal District, Telangana, India.
}

\section{Manuscript Info}

Manuscript History

Received: 12 July 2016

Final Accepted: 19 August 2016

Published: September 2016

Key words:-

Water quality, Lake, Statistical analysis

\section{Abstract}

The present investigation was under taken to study the Water Quality of Laknavaram Tank of Warangal, Telangana, India. This primary research was a period of one year from June 2015 to May 2016. The samples collected from two stations of Lake for the quality analisis.The Statistical analysis of one way analysis and Tukey test indicated significant deviation between factors with respect to seasons.

Copy Right, IJAR, 2016,. All rights reserved.

\section{Introduction:-}

Water is essential for life and the wellbeing of all the people. Natural water systems provides fisheries, flood plains, agriculture, natural services and products like aquifer replenishment, water quality improvement and bio-diversity (Banadda, 2011). The use of water bodies for recreational purposes is one of the most important aspects of ecotourism around the world. The main goal of the research was to assess the suitability of the urban Lake for recreational activities such as swimming, diving and boating to ensure the safety of users of the facility (BIS, 1991). From time immemorial ancient lakes has played a great role in human civilization as a precious life sustaining water resource. Antique architect and city planners were very much aware about the fact that lakes can improve the life quality of human civilization (Naselli-Flores, 2008). Thus they have usually constructed big lakes in almost all developed cities for great many purposes such as drinking water source, bathing and cleaning, agricultural irrigation, fishery, sustainable use for industry, boosting of natural ground water level, aesthetic value and many other livelihood. A healthy lake eco-system could conserve natural and social balance by contributing healthy environment of its location. Nowadays naturally existing dynamic equilibrium of water bodies like rivers, lakes and estuaries are affected by the human activities (Tamiru, 2004; Mahananda et al. 2010; Mehari and Mulu, 2013). In present scenario urban lakes are under direct threat of qualitative and quantities degradation by means of pollution from both fixed-point and non-point sources. There are numerous sources of pollutants that could deteriorate the quality of water resources (Tamiru, 2004). Factors that are directly or indirectly polluting the lake ecosystems includes population growth, unplanned growth of city area, urbanization, agricultural land expansion and lack of awareness among the local residents. All such activities and pollution causing factors are decreasing the utility of water day by day (Tank and Chippa, 2013). Accessible man maid urban lakes and all other natural wetlands have gained the thrust of conservation in recent years due to their important functions in different hydrological processes. To take decisions and formulate policies concerning conservation, management and sustainable use of lakes and water resources, accurate spatial inventory is required (Finlayson and Davidson, 1999). Thus, sequential and continuous interpretation of physical, chemical and biological status of water quality and characterization of the pollution sources along with quantitative contribution of significant pollution causing parameters is important for demeanor pollution control management of urban lakes (Zhou et al., 2011). This will generate baseline data of water resources to evaluate the rate of change in water quality over a period of time.

Corresponding Author:- Rev. Dr. J. W. Prakash.

Address:- Principal, Bishop Jesudasan Junior College, Etturnagaram, Warangal District, Telangana, India. 


\section{Study area}

A sprawling lake surrounded by a chain of beautiful green hillocks, serene waters with lush green islands dotting the expansive tank, hanging bridge and much more is here at the historic Laknavaram Lake. The lake, 65 kilometres from the Warangal district headquarters in Govindaraopetmandal, is spread in 10,000 acres. The entire tank is spread on a saucer-like land with hills and forest surrounding it. The lake, that holds about $2.135 \mathrm{tmcft}$ of water, irrigates over 3,500 acres in six villages surrounding it. It has about 13 islands in it and has a 160 meters long hanging bridge, which connects three islands. The sluice arranged by the Kakatiya kings is amid thick jungle at a narrow gap between natural hills is another spot worth seeing here.

\section{Materials and Methods:-}

The water samples were collected monthly from two selected stations $S_{1}$ and $S_{2}$ for a period of one year. The temperature was recorded at the time of sampling by using a standard thermometer. Oxygen content was measured by Wrinkler's method. The $\mathrm{pH}$ was measured with $\mathrm{p}^{\mathrm{H}}$ meter. All the other parameters were measured as per APHA (2005).

\section{Result and Discussion:-}

Monthly variation of physico - chemical characteristics are given in the table (1).

Seasonal Variation of Physico - Chemical Parameters (Water) at $(X \pm S D)$ Station I \& II during June 2015 to May 2016

\begin{tabular}{|c|c|c|c|c|c|c|c|}
\hline \multirow{2}{*}{$\begin{array}{l}\text { Sl. } \\
\text { No. }\end{array}$} & \multirow[t]{2}{*}{ Parameters } & \multicolumn{3}{|l|}{$\mathbf{S}_{1}$} & \multicolumn{3}{|l|}{$\mathbf{S}_{2}$} \\
\hline & & $\begin{array}{l}\text { Pre } \\
\text { monsoon }\end{array}$ & Monsoon & $\begin{array}{l}\text { Post } \\
\text { monsoon }\end{array}$ & $\begin{array}{l}\text { Pre } \\
\text { monsoon }\end{array}$ & Monsoon & $\begin{array}{l}\text { Post } \\
\text { monsoon }\end{array}$ \\
\hline 1. & Temperature ${ }^{\circ} \mathrm{C}$ & $29.62+0.5$ & $26.2 \pm 0.15$ & $28.3 \pm 0.65$ & $29.71 \pm 0.73$ & $26.32 \pm 0.34$ & $28.38 \pm 0.68$ \\
\hline 2. & $\mathrm{p}^{\mathrm{H}}$ & $6.98+0.35$ & $19.45 \pm 3.43$ & $6.93 \pm 0.17$ & $6.93 \pm 0.13$ & $6.63 \pm 0.85$ & $6.91 \pm 0.17$ \\
\hline 3. & Alkalinity $\mathrm{mg} / \mathrm{L}$ & $16.9+2.76$ & $13.75 \pm 3.5$ & $16.75 \pm 4.74$ & $20.73 \pm 2.99$ & $14.98 \pm 4.27$ & $15.2 \pm 2.98$ \\
\hline 4. & $\mathrm{DO} \mathrm{ml} / \mathrm{l}$ & $4.16+1.09$ & $6.03 \pm 0.62$ & $5.3 \pm 0.82$ & $4.11 \pm 0.88$ & $6.03 \pm 0.56$ & $5.25 \pm 0.76$ \\
\hline 5. & Phosphate & $0.03+0.005$ & $0.11 \pm 0.04$ & $0.06 \pm 0.03$ & $0.03 \pm 0.01$ & $0.09 \pm 0.08$ & $0.05 \pm 0.003$ \\
\hline 6. & Nitrate $\mathrm{mg} / \mathrm{L}$ & $1.28+0.87$ & $2 \pm 0.82$ & $1.5 \pm 0.58$ & $1.35 \pm 1.11$ & $2.05 \pm 0.76$ & $1.75 \pm 0.45$ \\
\hline
\end{tabular}

Temperature is the most important factor influences the aquatic productions. During the study period the temperature varied from $26.1{ }^{\circ} \mathrm{C}$ to $32^{\circ} \mathrm{C}$ at station $\mathrm{S}_{1}$ and $26^{\circ} \mathrm{C}$ to $34^{\circ} \mathrm{C}$ at stations $\mathrm{S}_{2}$. The mean value for the two stations shows a range of $26.01^{\circ} \mathrm{C}$ to $32.45^{\circ} \mathrm{C}$. (Table 1) Seasonal mean values were analyzed and highest value is recorded during premonsoon $(26.62 \pm 0.5 ; 29.71 \pm 0.73)$ followed by post monsoon $(28.3 \pm 0.65 ; 28.38 \pm 0.68)$ (Table 2) Observations on the statistical analysis of One way ANOVA and Tukey test for the two stations showed significant result between seasons $(\mathrm{F}=29.8 ; \mathrm{P}<0.01 ; \mathrm{F}=24.6 ; \mathrm{P}<0.01)$ but a non-significant result is observed between stations. Temperature is one of the most important ecological factors, which control the physiological behavior of the aquatic system and the distribution of biota (Das, 2000; Sedamkar and Angadi, 2003). The temperature varied from $26.01^{\circ} \mathrm{C}$ (June) to $30.3^{\circ} \mathrm{C}$ (May) at station where as in station II it is from $26^{\circ} \mathrm{C}$ (June) to $30.6^{\circ} \mathrm{C}$ (May) similar to the previous report in the present study. The recorded water temperature of water plays a significant role in determining the algal density. This finding agrees with Verma and Mohanty (1995); Jain et al. (1996); Harikrishnan et al. (1999) and Iwona and Lauri (2003). Statistical analysis indicated that water temperature showed a negatively significant result with $\mathrm{p}^{\mathrm{H}}$ and DO $\quad(\mathrm{r}=-0.973 ;-0.998 ; \mathrm{P} \leq 0.05 ;-0.967 ;-0.973, \mathrm{P} \leq 0.05)$ at both the stations.

$\mathrm{P}^{\mathrm{H}}$ is the one of the most important single factor, which influences aquatic production. During the study range $\mathrm{pH}$ was between 6 to $7 \mathrm{~S} 1$ and 5.4 to 7.4 at S2 (Table 1) The maximum pH value were recorded during summer season at two stations. It may be due to the high rate of photosynthesis of micro and macro vegetation resulting in high production of free $\mathrm{CO} 2$ during the equilibrium towards alkaline side. $\mathrm{pH}$ shows very low degree of negative correlation with carbonate alkalinity at station $\mathrm{S}^{1}$ and $\mathrm{S}^{2}$. The seasonal $\mathrm{pH}$ showed higher values during premonsoon $(6.98 \pm 0.05 ; 6.63 \pm 0.85)$ at station I and II respectively (Table 2). The analysis of One way ANOVA and Tueky test showed a significant result between season and stations. 
The acidity of alkalinity in neutral water is an importance chemical parameter linked with the distribution of aquatic organisms. The $\mathrm{pH}$ of the water ranged from 5.42 (February) to 7.4 (May) during the study period. The $\mathrm{pH}$ showed a gradual but significant increase in summer months. In monsoon months (June, July, August and September) it showed a decreased level and it remained high during post monsoon months. In general $\mathrm{pH}$ was low during monsoon and high during post monsoon and pre monsoon. Similar observation was reported earlier by Sreenivasan (1962) in Bhuvanisagar Reservoir). Benejea (1967) reported that both highly acidic and alkaline waters (pH 5.50 to 6.50 and $\mathrm{pH} 9$ and above) are unsuitable for good fish production. Alkaline nature is a usual feature of productive water bodies, Saxena and Adoni, 1973, 1973; Ayyappan and Gupta, 1981) Alkalinity may be due to the mineral which dissolve in water from soil. Alkaliniy in itself is not harmful to human being. The carbonate alkalinity was in the range between $10 \mathrm{mg} / \mathrm{L}$ to $19 \mathrm{mg} / \mathrm{L}$ at station $S_{1}$, where as in station $S_{2}$ it vary from $12 \mathrm{mg} / \mathrm{L}$ to $23 \mathrm{mg} / \mathrm{L}$. The mean value shows an increasing trend from $11 \mathrm{mg} / \mathrm{L}$ to $40.3 \mathrm{mg} / \mathrm{L}$ (Table 1 ) The seasonal means value revealed that at both the stations pre monsoon period showed high alkalinity $(16.9 \pm 2.76 ; 20.73 \pm 2.99)$ followed by post monsoon period $(16.75 \pm 4.75 ; 15.2 \pm 2.98)$ (Table 2$)$. The analysis of variance and Tukey test showed that the results were significant between seasons and stations $(\mathrm{F}=0.8 ; 1.1 ; \mathrm{P}>0.05 ; \mathrm{F}=2.7 \mathrm{P}>0.05)$.

A number of bases viz, carbonate, bicarbonates, hydroxide, phosphates, nitrates, silicates, borates contribute to alkalinity (Garg, 1998). Minimum level of total alkalinity needed for the water to be must productive is > 50ppm (Ohle, 1993). The minimum level of total alkalinity preferred for fish culturing is 100mg/1 (Schroeder, 1980). In the present study alkalinity although showed monthly fluctuations, it remained low during monsoon and high in pre and post monsoon months. This was due to the dilution effect and the result coincide to the earlier report of Khan et. Al (1996). Statically the alkalinity contents were significant between seasons and stations. Monthly variation of the nitrate content at Laknavaram Lake shows the maximum $27 \mathrm{mg} / \mathrm{L}$ at station I and $2.7 \mathrm{mg} / \mathrm{L}$ at station II during August and September respectively. The mean value for the two stations showed a high value of $3.65 \mathrm{mg} / \mathrm{I}$ in August and low value of $0.45 \mathrm{mg} / \mathrm{I}$ in May (Table 1) The result on One way analysis of variance and Tukey test indicated a significant deviation between stations only. $(\mathrm{F}=21.8 ; \mathrm{P}<0.05)$. A significant positive Correlation coefficient was observed with nitrate $(\mathrm{r}=0.960 ; 0.989 ; \mathrm{P} \leq 0.05$; at both the stations. The study area experienced a good deal of nitrate values during the monsoon months nitrate content supplied through flood washings carrying large amount of fertilizers used for agriculture from the adjacent lands, where through the flood has passed Chaulya et.al., 2002 and Sharma and Sarang, 2004). Verdium (1964) stated that the increase of fertilizers in the upstream. Deveraj et.al. (1988) observed similar trend of higher concentration during monsoon period in Hemavathy Reservoir.

The phosphate content of water is ranged from $0.02 \mathrm{mg} / 1$ to $0.12 \mathrm{mg} / 1$ at station I, from $0.03 \mathrm{mg} / \mathrm{I}$ to $0.21 \mathrm{mg} / \mathrm{I}$ at station. The mean value showed increasing trend from ok $\mathrm{mg} / 1$ to $2.4 \mathrm{mg} / \mathrm{L}$ respectively. (Table 1 ). Seasonal variations in the dissolved phosphate content revealed maximum concentration was encountered during the mansoon period $(0.1 \pm 0.04 ; 0.09 \pm 0.08)$ with decreasing trend in the post monsoon period $(0.06 \pm 0.03 ; 0.05 \pm 0.03)$. A significant positive Correlation coefficient was observed with $\mathrm{pH}(\mathrm{r}=0.934 ; 0.983 ; \mathrm{P} \leq 0.05)$ at both stations. The present investigation revealed that the dissolved phosphate concentration varied rapidly. During most of the months the reservoirs were characterized by low levels of phosphate. Earlier studies revealed such low levels of phosphate content in many of the Indian Reservoirs. (Sugunan, 1995). The values were found to be high during the monsoon. A similar instance was reported earlier by Devaraj et.al. (1988) in Hemavathy Reservoir. The high values during monsoon are due to the rain washings from the cathchment through river discharge and flood water (Hutchinson, 1941).

The minimum and maximum DOD level of station I was $0.8 \mathrm{mg} / \mathrm{I}$ (January) and $6.5 \mathrm{mg} / \mathrm{L}$ (May) but in station II the values were $0.48 \mathrm{mg} / \mathrm{L}$ (January) and 6.25/I (May) respectively. The mean values ranged from $0.78 \mathrm{mg} / \mathrm{L}$ (February) to $6.38 \mathrm{mg} / \mathrm{L}$ (may). (Table 1 ) The seasonal mean values were higher during premonsoon $(5.83 \pm 0.53 ; 5.76 \pm 0.41)$ and monsoon $(2.11 \pm 0.66 ; 2.12 \pm 0.63)$ period whereas post monsoon period recorded lower $(1.32 \pm 0.25 ; 1.19 \pm$ 0.52) values in the BOD level. (Table 2) On statistical analysis of One way ANOVA and Tukey test a significant result was obtained between stations $(\mathrm{F}=3199.0 ; \mathrm{P}<0.01)$ and non-significantresult was recorded between season. Correlation coefficient indicated a positively significant result with temperature $(\mathrm{F}=0.681 ; 0.67, \mathrm{P}<0.05)$.

The present study revealed a reduction of oxygen content during May. It is comparable to dissolved oxygen content in several fresh water bodies in India reported by De, 1999, Khabade et al. 2002. The reduction of oxygen is believed to have caused by high temperature, low bed level and dense growth of phytoplankton. Similarly a 
reduction, which was noticed towards the closure of monsoon, may be due to eutrophication. The present observation is similar to the previous observations made by Pathak (1979) in Nagajunasagar reservoir.

When seasonal mean values were compared the dissolved oxygen was high in monsoon and post monsoon. It is high velocity of wind that makes the water more oxygenated by mechanical admixture of air, water particles and intrusion of oxygen rich water through high inflow from the various riverlets (Sreenivasan, 1966). The low value of oxygen during the premonsoon season was due to the effect of high temperature and utilization of oxygen for the decomposition of organic matter and for respiration. A similar depletion of oxygen during premonsoon period was observed in Bhavanisagar (1962); Das and Varma (1993)

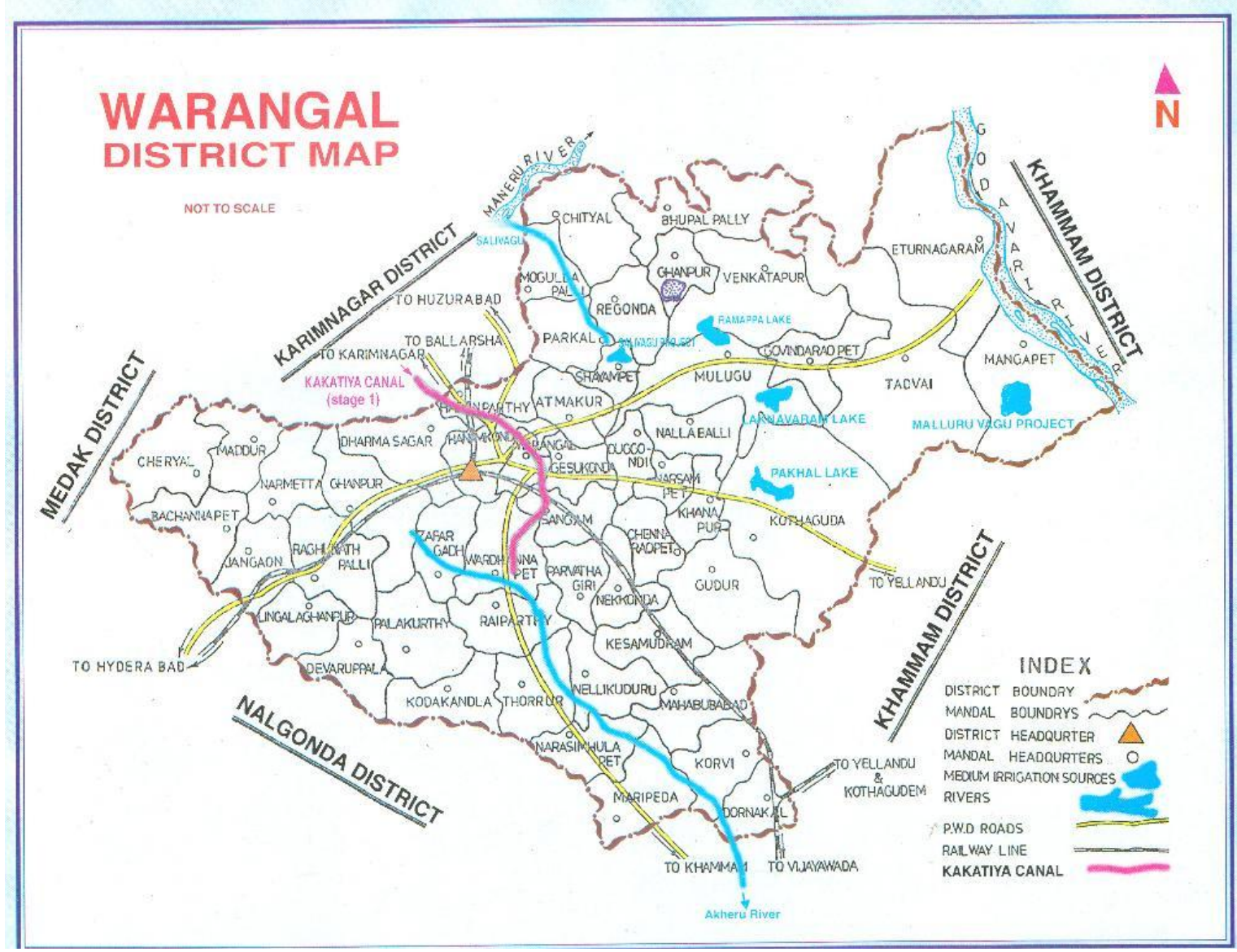

Map showing the water resources of Warangal District 


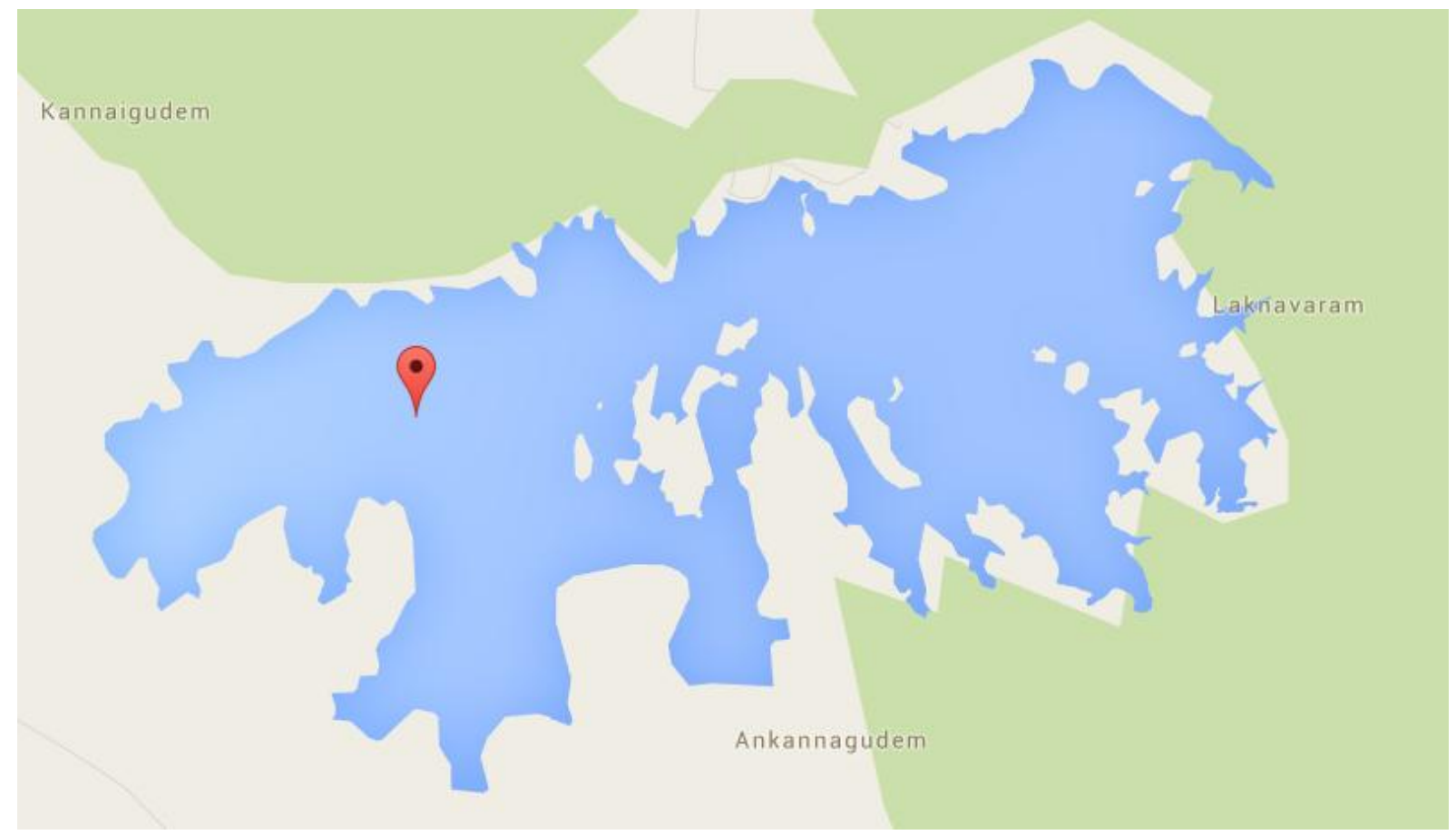

Map showing Laknavaram Lake at Warangal District

\section{Conclusion:-}

Laknavaram Lake is a tourist place of Warangal district. Even though the study area is a tourist place, there was any earlier research focus. The intensity of pollution is not that much high because of the low tourist interference. When tourist interference become high, there is a chance of pollution in the beautiful Lake. So there should be proper directions to be away from the polluting activities.

\section{Acknowledgement:-}

Author would like to thank the friends who are along with us throughout the study. Especially I am thankful to the forest Department Etturnagaram, Bishop DharmarajRassalam and Office bearers, Higher Education Society of C.S.I. South Kerala Diocese, Board for Mission, C.S.I. South Kerala Diocese, officers of Bishop Jesudasan Junior College, Dr.G.S.ReginiBalasingh (Emirates scientist, Department of Botany and Research Centre, Scott Christian College, Nagercoil), Dr.L.B.S. Irence,Dew Juswil, Reju Justin (Research Scholar, Department of Botany and Research Centre, Scott Christian College, Nagercoil), Jimry S. Kumar (Technical Assistant) and Justin Raj. J. T (Field Assistant) for their continuous encouragement and support to fulfill this primary research work

\section{References:-}

1. De. U.K. 1999 seasonal variation of some abiotic factors of two fresh water ponds. Geobios., 18: 119-121.

2. Khabade, S.A., M.B. Mule and S.S. Sathe, 2002. Studies on physico - chemical parameters of Iodhe water reservoir from TaraonTabsil (Maharashtra) Indian J. Environ and eco plan6(2): 301 - 304.

3. Ayyappan, S. T.R. Gupta 1981. Limnology of Ramsamudra tank - Hydrograph, Mysore J. Agric SC., 15 : 305 $-312$.

4. Banerjea, S.M. 1967 water quality and soil condition of fish ponds in some states of India in relation to fish production. India . J. Fish. 14 (1\&2) : $115-144$.

5. Chaulya, S. R.S. Singh and S.K. Chaulya, 2002. Ecological study of a pond a Jharia Coal field IJEP22(8) : 914 $-921$.

6. Das, A.K. 2000, Phytoplankton Primary Production in some selected reservoirs of Andhrapradesh.Geobios 29, $52-57$.

7. Devaraj, K.V. H.S. Manadeva and A. Afzal, 1998, Hydrobiology of the hemavathy reservoir. In M. Mohan Joseph (ed). The first Indian Fisheries forum, Asian Fishers Society Indian Branch, Mangalore. Proceedings pp323- 327. 
8. Garg, S.K. 1998 Sewage disposal and air pollution engineering. Environmental engineering Vol. II, $11^{\text {th }}$ Ecology Khanan publications $188-189$.

9. Iwona, I. and Cauri, A 2003. Potential effects of abiotic factors on the abundance of autotropic plankton in four lakes. J. Plankton Res., 25 (8) : $873-883$.

10. Harikrishnan, K., S. Thomas, S. George, R.P. Murugan, S. Mudayoor, and M.R. Das 1999. A study on the distribution and ecology of phytoplankton in the Kuttanad wetland ecosystem, Kerala, Poll. Res 18(3) 261 269.

11. Das, H.N. and B.N. Verma 1993 Limnology of a pond and lake at Rajnager (Madhubant) BiharBio.Journal 5: 1 -6 .

12. Jain, S.M. M. Sharma and R. Thakur, 1996. Seasonal variations in Physico - Chemical parameter of Halali reservoir of Vidisha district, India, J. Ecobiol., 8(3) : 181 - 188.

13. Khan, M.A., Singh, H.P., Davived, R.K. Singh, P.N. and Tyagi, R.K. 1996. Ecology and fish yield from Baghabla Reservoir. A small impartment in Ganga Basin J. Inland Fish. Soc. India 28(2) : 91 - 100.

14. Oble, W. 1993 Chemisch - Stratigraphicheuntersuchungen sediment Metamos - Pho Zeenes world sees. Biochem. Z. $258: 420-428$.

15. Puthak, V. 1979 Evaluation of Productivity in NagarganSagarReservoit (Andhra Pradesh) as a function of hydro biological and limno - Chemical Parameters I. Inland Fish. Soc. India, 11(2) : $49-68$

16. Saxena, S.B. and A.D. Adoni 1973 Diurnal variation in sagar lake, sagar (India) studies in deep water areas, Hydrobiol, 42 : 435 - 443.

17. Sharma, L.L. and S. Saromg, 2004. Physico - Chemical limnology and productivity of Jai Samandlake, Udaipur (Rajashthan) Poll. Res., 23 (1) : 87 - 92.

18. Sreenivasan, A. 1962 Anote on the hydrology of Bhavanisagar for 1956 - 61 Madras J. Fish., 1:70 - 71.

19. Sreenivasan, A. 1966 Limnoloyg of tropical impoundment, Hydrobiologial and fish production in Stanley Reservoir, Mettar Dam Inst. Rev. Ges. Hydrobiol, 51 (2): 295 - 306.

20. Sedamkar, and Angadi, S.b. 2003 Physico - Chemical parameters of two freshwater bodies of Gulbarga India, with special reference to phytoplankton Poll. Res. 22(3) : $411-422$.

21. Verduin, J. 1964 Charges in western lakEri during the period 1948 - 1962. Verh. Int. ver. Limno15: 639 - 644.

22. Verma, J.P. and Mobarty, R.C. 1995. Plytoplankton and its correlation with certain plysico - chemical parameters of Danmukundpur pond, Poll Res. 14(3): 223 - 242.

23. APHA, 2005. Standard methods for the examination of water and waste water (21st ed.), Washington, D.C: American Public Health Association.

24. Finlayson, C.M. and Davidson, N.C. (collators), 1999. Global Review of Wetland Resources and Priorities for Wetland Inventory: Summary report, in Global Review of Wetland Resources and Priorities for Wetland Inventory, Finlayson, C.M. and Spiers, A.G., Ed., CDROM, Supervising Scientist Report 144, Canberra, Australia.

25. Francis-Floyd, R., 2003. Dissolved Oxygen for Fish Production. Fact Sheet FA 27. Florida: Department of Fisheries and Aquaculture, Florida Cooperative Extension Service, Institute of Food and Agricultural Sciences, University of Florida.

26. Mahananda, M.R., Mohanty, B.P. and Behera, N.R., 2010 Physico-chemical analysis of surface and ground water of bargarh district, Orissa, india, International Journal of Research and Reviews in Applied Sciences, vol.2(3), pp. 284-295.

27. Mehari, M. and Mulu, B., 2013. Distribution of Trace Metals in Two Commercially Important Fish Species (Tilapia Zilli and OreochromisNiloticus) Sediment and Water from Lake Gudbahri, Eastern Tigray of Northen Ethiopia, International Journal of scientific and Research Publications, vol. 3, pp. 2250-3153.

28. Naselli-Flores, L., 2008. "Urban Lakes: Ecosystems at Risk, worthy of the best care", in Proceeding of Taal 2007: The 12th World lake conference, Sengupta, M. and Dalwani, R., Ed., pp. 1333-1337.

29. Tamiru, A., 2004. Assessment of Pollution Status and Groundwater vulnerability Mapping of the Addis Ababa Water Supply Aquifers, Ethopia.

30. Tank, S. K. and Chippa, R.C., 2013. Analysis of Water Quality of Halena Block in Bharatpur Area, vol.3(3), International Journal of Scientific and Research Publications.

31. Zhou, F., Guo, H.C., Liu, Y. and Jiang, Y.M., 2011. Chemometrics data analysis of marine water quality \& source identification in southern Hong Kong, Marine Pollution Bulletin 54 (6), pp. 745-756.

32. Banadda N.(2011) Characterization of non point source pollutants and their dispersion in Lake Victoria Uganda. African Journal of Environmental Science and Technology Vol. 5(2), pp. 73-79, February, ISSN $1996-0786$.

33. Bureau of Indian Standards „Lake Water - Specification (First revision) September, 1991, BIS, New Delhi. 